\title{
DISCOVERY OF THE PATAGONIAN SPECIES RANUNCULUS FUEGIANUS SPEG. (RANUNCULACEAE) IN THE ALTIPLANO PEATLANDS OF NORTHERN ARGENTINA AND ITS LECTOTYPIFICATION
}

\author{
DESCUBRIMIENTO DE LA ESPECIE PATAGÓNICA RANUNCULUS \\ FUEGIANUS SPEG. (RANUNCULACEAE) EN LOS BOFEDALES DEL \\ ALTIPLANO DEL NORTE DE ARGENTINA Y SU LECTOTIPIFICACIÓN
}

\author{
Carlos A. Lehnebach ${ }^{1}$, Karsten Schittek $^{2} \&$ Laura Iharlegui $^{3}$
}

\begin{abstract}
${ }^{1}$ Museum of New Zealand, Te Papa Tongarewa, Cable St, PO Box 467, Wellington. New Zealand; ${ }^{2}$ Seminar für Geographie und ihre Didaktik, Gronewaldstr. 2, 50931 Köln, Germany; ${ }^{3}$ División Plantas Vasculares, Museo de La Plata, Paseo del Bosque s.n., B1900FWA La Plata, Argentina. carlosl@tepapa.govt.nz; c_lehnebach@hotmail.com
\end{abstract}

\section{RESUMEN}

Ranunculus fuegianus es una especie sudamericana comúnmente considerada como endémica de la Patagonia y Tierra del Fuego. En recientes excursiones al norte de Argentina se han descubierto dos poblaciones de R. fuegianus en las localidades andinas Abra del Gallo e Incachule (Provincia de Salta, $24^{\circ} \mathrm{S}$ ). Con este registro se extiende el límite norte de distribución de esta especie en Argentina en más de $2.500 \mathrm{~km}$. Se propone, además, la lectotipificación de $R$. fuegianus con material original depositado en el herbario LP.

Within Ranunculaceae, Ranunculus is the most speciose genus and about 600 species have been described (Tamura 1995). Ranunculus is worldwide distributed and although its diversity is greater in the Northern Hemisphere, the number of species in the Southern Hemisphere is not less significant. Within South America, the diversity of Ranunculus appears to be greater in the southern most end of the continent, in Patagonia. About 18 species have been recorded here, many of them growing sympatrically (Lourteig 1951, Ruiz 2002). A species commonly considered endemic to Patagonia is Ranunculus fuegianus Speg. (Lourteig 1951, Moore 1983, Lourteig 1984, Ruiz 2002). This species is usually found in moist sites by freshwater streams, swamps and seasonal pools. Plants of $R$. fuegianus are morphologically variable depending on water levels. Stems can be creeping and stout or submerged with slender petioles and floating leaves. Plants are glabrous with leaves sub-pentagonal to sub-orbicular in outline, deeply 3-partite with 2- to 3-lobed segments. Flowers can be solitary or arranged in cymes, with 3-5 sepals and 5 yellow petals. The receptacle may contain up to 65 achenes. These can be finely foveolate to smooth, with short and curved beak. A thick layer of parenchyma covers the carpel wall which may assist in flotation and water dispersal. A detailed description of $R$. fuegianus can be found in Lourteig $(1951,1984)$.

Lourteig (1951) revised the temperate South American representatives of Ranunculaceae. In this study, she studied all members of Ranunculus and provided revised descriptions and details on their synonymy and types. While studying the distribution of $R$. fuegianus we revised the material Lourteig (1951) indicated as type of this species and discovered it consisted of multiple collections and therefore further lectotypification was required. In this note we extend the northern limit of distribution limit of distribution of $R$. fuegianus based on new collections in northern Argentina and designate a lectotype for the species selected from Spegazzini's original material at LP. 
NEW NORTHERN LIMIT OF $R$. FUEGIANUS

Currently, the northern limit of distribution of $R$. fuegianus is located at ca. $46^{\circ} \mathrm{S}$ in Chile (Provincia de Aisén) and ca. $49^{\circ} \mathrm{S}$ in Argentina (Provincia de Santa Cruz) (Zuloaga \& Morrone 1999, Ruiz 2002). Results from recent botanical expeditions to northern Argentina by the second author of this work, however, have proved different. Large populations of $R$. fuegianus have been discovered in the Andean localities of Abra del Gallo (2419'S; 66 $28^{\circ} \mathrm{W}$; ca. 4500 masl) and Incachule (24 $16^{\prime} \mathrm{S}$; $66^{\circ} 27^{\prime} \mathrm{W}$; ca. 4400 masl), Provincia de Salta, Northern Argentina (Fig. 1). These localities are more than $2500 \mathrm{~km}$ north from the previously reported northern limit for this species in Argentina. The extra-Patagonian

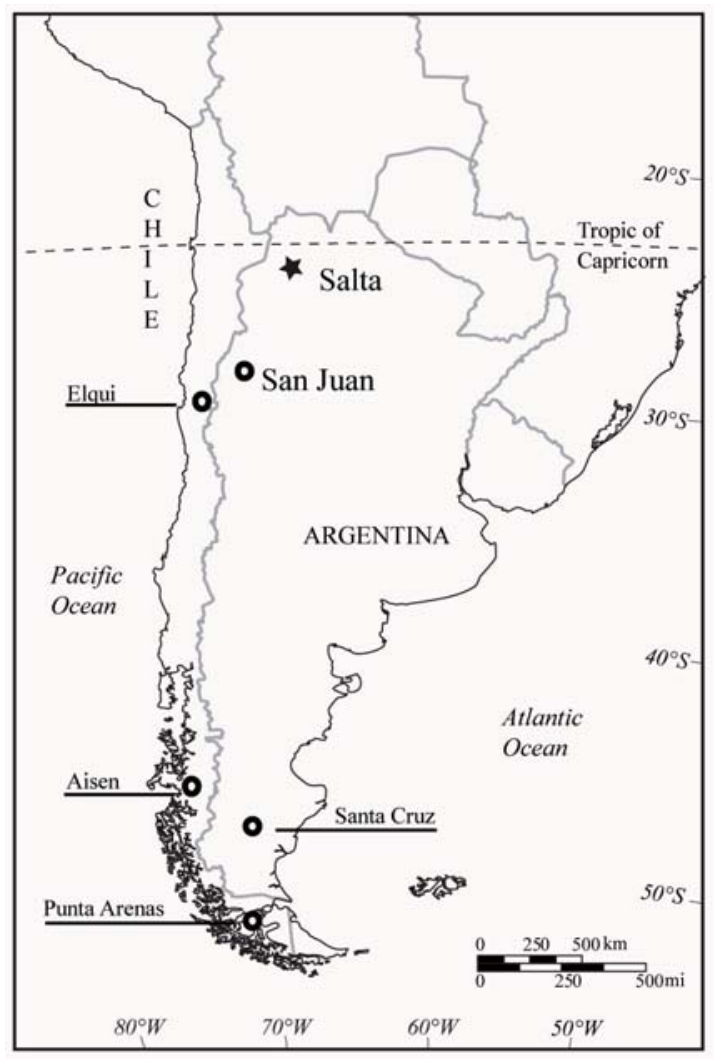

FiguRE 1. New collection of Ranunculus fuegianus at Provincia de Salta in northern Argentina $(\star)$ and previous collections in Chile and Argentina $(\mathbf{O})$ studied here.

Figura 1. Nueva colecta de Ranunculus fuegianus en la Provincia de Salta, Argentina $(\star)$ y previas colectas en Chile y Argentina (0). occurrence of $R$. fuegianus is further supported by previous collections at Provincia de San Juan (29¹7'S; 6958'W, $3700 \mathrm{masl})$ about $500 \mathrm{~km}$ south of Abra del Gallo, also in Northern Argentina (Fig. 1) and vega Piuquenes, Provincia de Elqui, IV Región de Coquimbo, Chile (Fig. 1) by Ruthsatz (personal communication to the second author). These collections had been overlooked because they had been identified only to the genus level or misidentified with $R$. flagelliformis Sm. Unlike $R$. fuegianus, this species has entire leaves (see identification key in Ruiz 2002).

In these extra-Patagonian settings, $R$. fuegianus is found in high altitude peatlands (bofedales) formed at valley bottoms. Surrounded by an otherwise dry landscape, these soligenous peatlands are fed by groundwater from snowmelt, rain and thermal spring waters (Schittek in prep., Squeo et al. 2006). The vegetation here is dominated by Distichia muscoides Nees et Meyen and Oxychloe andina Phil. (Juncaceae). These densely growing cushion-former species can form extensive carpets, often interrupted by clusters of small and shallow pools, more or less interconnected with local rivulets or small streams (Ruthsatz 2008). It is in these slow-moving waters where $R$. fuegianus is preferentially found along with Myriophyllum quitense Kunth (Holoragaceae) and Potamogeton strictus Phil. (Potamogetonaceae). Interestingly, the latter two species are also found in Patagonia (Moore 1983).

\section{LECTOTYPIFICATION OF $R$. FUEGIANUS}

Ranunculus fuegianus was originally described by Carlos Spegazzini in 1896 in his work "Plantae per Fuegiam a Carolo Spegazzini anno 1882 collectae" published in Anales del Museo Nacional de Buenos Aires. In this work, Spegazzini reports the discoveries made as a botanist in the expedition of Lieutenant S. Bové to Patagonia and Tierra del Fuego during 1881-1882 (Katinas et al. 2000). Although the description of $R$. fuegianus in this work is fairly comprehensive, he failed to designate a type specimen. However, habitat details and the collection localities are given in the protologue: "in piscinis et rivulis substagnantibus non rarus: Punta Arenas, Sarmiento Fjord, Ushuuáia [Ushuaia]". The description of $R$. fuegianus is accompanied by an illustration that depicts the plant habit and details of flowers and achenes.

The collection of Carlos Spegazzini, formerly 
at the Instituto de Botánica Carlos Spegazzini (LPS), is currently kept at LP (Museo de La Plata, Buenos Aires, Argentina). This collection includes specimens of $R$. fuegianus collected by Spegazzini at Punta Arenas (LPS 12582) and Ushuaia (LPS 12581), both localities mentioned in the protologue. The material collected at Punta Arenas and numbered LPS 12582 has been designated as the type (lectotype) of $R$. fuegianus by Lourteig (1951) in her revision of the temperate South American Ranunculus. This was also the only material of $R$. fuegianus from LPS that Lourteig examined in her revision of this species. She also indicated that a duplicate of this material can be found at $\mathrm{K}$. Attempts to locate material matching the details indicated by Lourteig at Kew have been futile (search was done by Dr. Tony Orchard, Australian Botanical Liaison Officer at Kew, pers. com.). Examination of Spegazzini's collections at LP has showed that LPS 12582 consists of three sheets, all bearing the same number. From these three specimens, two are labelled "co-typus" and two of them have the inscription "P. Arenas" handwritten by Spegazzini. Lourteig (1951) did not specify which one of the three sheets of LPS 12582 is the lectotype of $R$. fuegianus. As suggested in Art. 9.15 of the ICBN (McNeill et al. 2006), lectotypification of $R$. fuegianus should be narrowed down to a single specimen and subsequent lectotypification is required. After studying the three sheets of LPS 12582 we have selected as the final lectotype of $R$. fuegianus the material mounted on the sheet with the collection locality "P. Arenas" hand written by Spegazzini, the word "co-typus" stamped on it and with a LPS label (Fig. 2). This material matches with the description of $R$. fuegianus presented in the protologue by Spegazzini (1896).

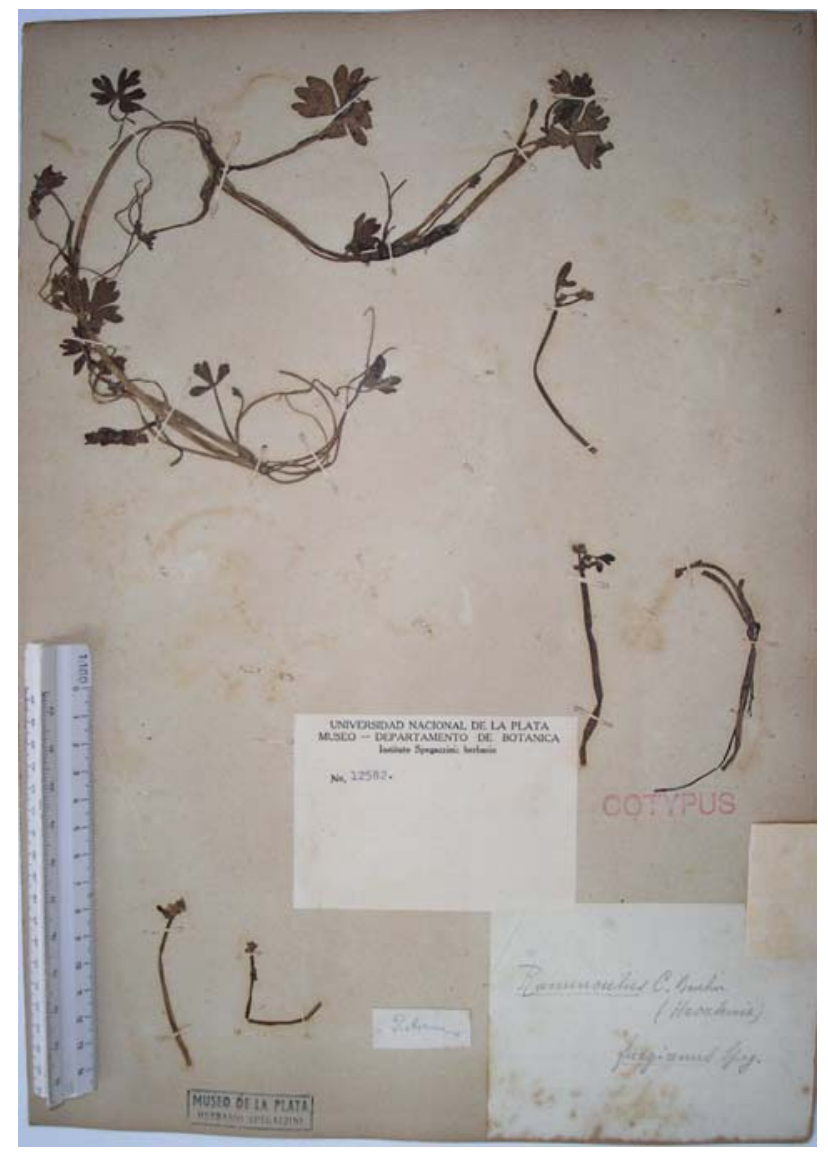

FIgURE 2. Lectotype of Ranunculus fuegianus Speg. at LP.

Figura 2. Lectotipo de Ranunculus fuegianus Speg. en el herbario LP. 


\section{Ranunculus fuegianus Speg.}

C. Spegazzini, Anales Mus. Nac. Hist. Nat. Buenos Aires 5:43, Fig. 3a. 1896.

"Hab. In piscinis et rivulis substagnantibus non rarus: Punta Arenas; Sarmiento Fjord; Ushuuáia [Ushuaia]"Lectotype (designated here): "P. Arenas [Chile]", Spegazzini s.n. (LPS 12582 at LP!), Isolectotypes: Spegazzini s.n. (LPS 12582 at LP!).

Note: The two isolectotypes of LPS 12582 can be easily identified. One of them is mounted one a paper envelope and the other one on a sheet with no LPS label or "co-typus" stamp on it and the specimen number is handwritten on the lower left corner.

\section{SPECIMENS STUDiED}

ARGENTINA: Salta. Depto. de los Andes: Abra del Gallo, cushion mire. 23-II-2007, K. Schittek, V640701 (WELT). San Juan. Depto. Iglesia: Valle de la Iglesia, R. Kiesling et al. 8684 (SI). Tierra del Fuego, Antártida e Islas del Atlántico Sur. Depto. Ushuaia, Spegazzini s.n. (LP).

CHILE: XII Región de Magallanes, Provincia de Magallanes, Punta Arenas, 17-II-2003, Lehnebach s.n. (MPN).

\section{ACKNOWLEDGMENTS}

We thank A. Chemisquy, F. Flores, L. Lupo, O. Morrone, G. Sancho, T. Orchard, B. Ruthsatz, D. Werner and J. Zenón for their great help over various stages of this study. Funding from the National Geographic Society (Grant \#8030-06), the German Federal Ministry of Education and Research (Project ARG 06/009) and the National University of Jujuy to $\mathrm{KS}$. We also thank reviewers for their valuable comments.

\section{REFERENCES}

Katinas, L., D.G. Gutiérrez \& S.S. Torres Robles. 2000. Carlos Spegazzini (1858-1926): travels and botanical work on vascular plants. Annals of the Missouri Botanical Garden 87: 183-202.

Lourteig, A. 1951. Ranunculáceas de Sudamérica templada. Darwiniana 9(3-4): 445-608.

Lourteig, A. 1984. Ranunculaceae. En: M.N. Correa (ed.), Fl. Patag. 8(4a), pp. 284-322. Colección Científica Instituto Nacional Tecnología Agropecuaria.

McNeill, J., F.R. Barrie, H.M. Burdet, V. Demoulin, D.L. Hawksworth, K. Marhold, D.H. Nicolson, J. Prado, P.C. Silva, J.E. Skog, J.H. Wiersema \& N.J. TuRLAND. 2006. International Code of Botanical Nomenclature (Vienna Code) adopted by the Seventeenth International Botanical Congress Vienna, Austria, July 2005. Regnum Vegetabile 146.

Moore, D.M. 1983. Flora of Tierra del Fuego. Missouri Botanical Garden Press, Missouri-St Louis. 396 pp.

RuIz, E. 2002. Ranunculaceae. En: C. Marticorena \& R. Rodríguez (eds.), Flora de Chile, vol. 2, pp. 40-84. Ediciones Universidad de Concepción, Concepción, Chile.

RuthsATZ, B. 2008. Hartpolstermoore der Hochanden NWArgentiniens als Indikatoren für Klimagradienten. In: J. Dengler, C. Dolnik \& M. Trepel (eds.), Flora, Vegetation und Naturschutz zwischen Schleswig-Holstein und Südamerika, vol. 65, pp. 209-238. Mitteilungen der Arbeitsgemeinschaft Geobotanik in Schleswig-Holstein und Hamburg. Kiel. Germany.

SpegazZINI, C.L. 1896. Plantae per Fuegiam a Carolo Spegazzini anno 1882 collectae. Anales del Museo Nacional de Historia Natural, Buenos Aires 5: 39-104.

Squeo, F.A., B.G. Warner, R. Aravena \& D. Espinoza. 2006. Bofedales: high altitude peatlands of the central Andes. Revista Chilena de Historia Natural 179: 245-255.

Tamura, M. 1995. Systematic Part. In: P. Hiepko (ed.), Die Natürliche Pflanzenfamilien: Ranunculaceae, pp. 223-519. Duncker \& Humboldt, Berlin.

Zuloaga, F.O. \& O. Morrone. 1999. Ranunculaceae. En: F. Zuloaga \& O. Morrone (eds.) Catálogo de las Plantas Vasculares de la Argentina: Dicotyledoneae, pp. 964-974. Monographs in Systematic Botany from the Missouri Botanical Garden 74. 